\title{
Socio-Economic Risk Assessment and Peril Analysis in the Context of the COVID-19 Pandemic and Emergencies
}

\author{
By Olga Novikova ${ }^{1}$, Olena Khandii ${ }^{2}$, Larisa Shamileva ${ }^{1}$
}

\begin{abstract}
The article proposes a methodology for assessing socio-economic risks and analysing perils in the context of the COVID-19 pandemic and emergencies, and presents the results of its testing. The methodology allows assessing changes in labour risks by possible values of internal indicators. This makes it possible to develop scenario approaches in case of a change in quarantine restrictions or their lifting. Testing of the developed methodology for assessing socio-economic risks and analysing perils caused by the impact of the COVID-19 pandemic on the domestic labour market and employment is based on determining changes in economic conditions of risk emergence and occurrence, direct employment risks, and assessment of socio-economic consequences of risks in case of strict quarantine measures during the $2^{\text {nd }}$ quarter of 2020. A feature of the proposed scientific and methodological support for assessing socio-economic risks and analysing perils in the context of the COVID-19 pandemic is taking into account the basic principles of the European system of social indicators using quantitative methods of assessing social risks in the workplace. The practical significance of the obtained results is that the introduction of the developed scientific and methodological support, and practical recommendations will promote the development of preventive measures to deal with socioeconomic risks and perils in the domestic labor market and employment, to improve social protection during the COVID-19 pandemic, and to prioritise the government measures based on the risk ranking according to the occurrence, and the impact probability.
\end{abstract}

Keywords: socio-economic risks and perils, labour market, employment, pandemic, quarantine restrictions

\section{Introduction}

The impact of the COVID-19 pandemic in the domestic labour market is accompanied by a direct or indirect decline in the engagement of manpower in economic activity. This impact is related to both direct temporary prohibition or restriction of certain economic activities, and termination/restriction of labour migration. The indirect impact is connected with a decrease in demand leading to the economic recession. Consequently, it reduces the need for manpower. During the pandemic, the main changes in the domestic labour market as well as in the world markets are related to declining employment and labour migration, rising unemployment, falling incomes, loss of jobs and income of individual entrepreneurs.

All the given conditions cause many risks in the system of social and labour relations and employment, which have negative socio-economic consequences. Table 1 summarises them. 
Table 1. Systematisation of social risks in the labour sphere and their consequences in the context of the COVID-19 pandemic

\begin{tabular}{|l|l|}
\hline Risk & Economic and Social Consequences \\
\hline 1. Rise of unemployment & 1. Decline in employment \\
2. Part-time employment, & 2. Spread of hidden unemployment \\
underemployment, forced & 3. Spread of unemployment \\
unpaid leave & 4. Spread of poverty and population differentiation \\
3. Loss of earning, income & 5. Inconsistency of employment with the educational and \\
4. Informal and shadow & professional background \\
employment & 6. Loss of social status, broken social elevators \\
5. Remote work & 7. Decrease in consumer demand due to the decrease in \\
6. Inefficient work & purchasing power of the population, in particular: lack of \\
7. Decrease in demand for & possibility to use paid services; loss of possibility and \\
manpower in the labour & availability of mortgage lending, etc. \\
market & 8. Debt increase, e.g. loan payments, rent, housing and \\
8. Loss of working hours & communal services, and the like. \\
9. Unprotected employment, & 9. Demotivation for learning and professional development \\
social insecurity & 10. Lack of demand for manpower \\
10. Labour migration & 11. Decrease in the educational and labour potential, human \\
& capital \\
12. Social insecurity \\
13. Social alienation, social isolation, social maladaptation \\
14. Restriction of internal labour migration, including \\
pendulum
\end{tabular}

Source: developed by the authors

At the beginning of the introduction of strict quarantine measures, the main employment risks were connected with rising unemployment due to the closure of enterprises in the service sector, wholesale and retail trade, temporary accommodation and catering, transport, and other economic activities. Enterprises of other sectors of the economy, including industry and construction, also partially closed down. That situation was accompanied by a significant loss of working hours.

The main ways of optimising the losses of employers under these conditions were as follows:

- total shutdown of some enterprises and consequently dismissal of employees;

- dismissal of employees "upon the mutual agreement of the parties" providing an opportunity for employers to save on severance pay, but it is accompanied by loss of income and increase in social insecurity of employees;

- making employees take unpaid leave or a part-time job, which provides an opportunity to save the number of employees, but leads to a loss of income and deepening social insecurity. As a result of part-time employment, underemployment or unpaid leave, there appears "hidden unemployment" with the corresponding level of social insecurity and social exclusion. "Hidden unemployment" also includes persons who are employed 
without registration, i.e. employed informally or according to shadow (illegal) employment schemes;

- introduction of remote employment leading not only to maintaining a certain level of employment, but also creating additional risks of social insecurity of workers.

The main socio-economic consequences of the occurrence of social risks in the system of social and labour relations are connected with a decline in employment, significant loss of working hours, and low productivity. A decrease in demand for manpower with excessive supply is accompanied not only by a decline in employment but also by the spread of inefficient work that does not meet the criteria of decent. This situation leads to the workers' demotivation, and reduces the opportunities for their development.

During the period of strict quarantine measures, living conditions have significantly worsened, which is a potentially threatening situation for the population welfare. Loss of income, rise of complete or partial unemployment leads to deepening socio-economic inequality in society.

One of the most important economic negative consequences of risks in the labour sphere is a decrease in consumer demand, and changes in the structure of income and expenditure of the population. An increase in the share of social transfers in the income structure and a decrease in the share of expenditures on savings significantly narrow the opportunities for further economic development, and cause GDP decline. Consumer demand is decreasing due to the fall in purchasing power. The possibility to use paid services is getting lower; the availability of mortgage lending is reducing; debts of rent payments, housing and communal service payments are increasing.

More indirect negative consequences may appear over time, especially if the coronary crisis and quarantine measures continue even in case of an adaptive quarantine. These consequences are connected with a decrease in the educational and labour potential of the country, lack of demand for manpower, and consequently, demotivation for learning and professional development. All the given economic consequences generally lead to social consequences, in particular, deepening social insecurity, social exclusion and isolation.

It should be noted that the impact of labour migration risk was not as significant as it had been expected at the beginning of the pandemic. Thus, 2-3 weeks after the pandemic, migrants who had returned to Ukraine began to look for ways to return back due to the absence of decent jobs (sufficient salary, compliance with the professional background, etc.)

All the given negative consequences of social risks in the labour sphere are simultaneously accompanied by precarity of the employed population and manpower, regressive social mobility due to the middle class shrinking in the total population, and can lead to destabilisation in society and protest sentiments. Such scenarios may occur if quarantine measures are continued, and a prudent government policy for preventing or mitigating the cosequences is absent.

\section{Methodology}

Methods for assessing socio-economic risks and analysing perils in the labour sphere under quarantine restrictions

The development of effective programmes to prevent or mitigate the negative 
consequences of social risks requires their quantitative assessment, determining the impact of individual components on changes in the risk level.

Currently, there are three basic methodological approaches to assessing social risks (Nadraha, 2013; Nadraha, 2015; Berezina, 2018). The first one involves assessing the probability of risk occurrence under certain conditions. The second approach is an objective complement to the first approach. It includes an assessment of possible losses in cost, quantity, and labour contexts in case of a risk. These two approaches are based on large amounts of statistical information over quite a long time. Based on the fact that social risks in the labour sphere emerge and occur within a limited time (from six months to a year) during the coronavirus crisis, and the consequences may appear either at the time of the risk occurrence or with a certain delay (one or two years in a row), then the use of these two approaches is quite problematic.

Given the above limitations, the methodology for quantitative assessment of social risks in the labour sphere under quarantine should be developed taking into account the basic principles of the European System of Social Indicators (ESSI) (Saienko, 2004; Novikova et al., 2020; Sydorchuk, 2018). They are determined in the coordinates of identity, inequality, consolidation, conflict, and based on the use of the most objective databases available at the time of the study. It should also be noted that the developed approach to risk assessment makes it possible to assess not directly its level of development, but its changes (in the rate or ratio contexts) by assessing the impact of all internal components that determine these changes. This approach provides a possibility to fully determine the factors of change in social risks aimed at developing appropriate management decisions to minimise the negative consequences of their occurrence.

In a general form, the methodology for assessing the risks in the labour sphere under the COVID-19 crisis is based on the following starting points:

1. The main conditions of the social risk occurrence in the system of social and labour relations (SLR) include the following components:

- change in the economic situation in the country during the period of quarantine restrictions and the coronavirus crisis;

- change in the unemployment level in the labour market;

- socio-economic consequences of the risk occurrence in the labour sphere.

2. For each component, the corresponding sub-indices $\left(I_{i}\right)$ are determined, which are calculated as quantitative estimates of changes in risks during a certain period:

- change in economic conditions of the risk emergence and occurrence in the labour sphere (I $I_{\text {ch.econ.cond.); }}$;

- change in unemployment in the labour market $\left(I_{\text {ch.unempl. }}\right)$;

- change in losses in case of the risk occurrence $\left(I_{\text {cb.loss. }}\right)$.

For each $i$-th component, the corresponding sub-indices are determined that provide their quantitative assessment in the following ratio:

$I_{i}=\sqrt[\sum W_{j}]{\prod_{j=1}^{n_{i}} k_{i j t}^{W_{j}}}$

[formula 1]

where $I_{i}$ is a sub-index as for the $i$-th component; $\mathrm{i}=1,2,3$;

$k_{i j t}$ is the coefficient of change in the $j$-th indicator of the $i$-th component in the $t$-th period.

To determine the unidirectional impact of indicators on the change of risks, indicators are calculated as stimulators (direct impact) and destimulators (reverse effect). Under these 
conditions, the calculation of the subindex include stimulators in the following ratio:

$k_{i j t}=\frac{x_{i j t}}{x_{i j t-1}}$

And destimulators are included according to the reverse ratio:

$k_{i j t}=\frac{x_{i j t-1}}{x_{i j t}}$,

where $x_{i j t}, x_{i j t-1}$ is the value of the $j$-th indicator of the $i$-th subindex per $t$ and (t-1)-th periods;

$W_{j}$ is the weighting coefficient of the $j$-th indicator;

$W_{j}$ is determined as the proportion of persons affected by the corresponding indicator. If $\sum_{j=1}^{n_{i}} W_{j}=1$, then the $i$-th subindex is calculated by the formula of the multiplicative factor model:

$I_{i}=\prod_{j=1}^{n_{i}} k_{i j t}^{W_{j}}$ or

$I_{i}=k_{i 1 t}^{W_{1}} \cdot k_{i 2 t}^{W_{2}} \cdot \ldots \cdot k_{1 n_{i} t}^{W_{n_{i}}}$.

[formula 2]

3. The composite index of the risk change in the social and labour relations is calculated as a geometric mean using the determined sub-indices

$I_{S L R \text { risk }}=\sqrt[3]{\left(I_{1}^{W_{1}} \cdot I_{2}^{W_{2}} \times I_{3}^{W_{3}}\right)}$

[formula 3]

In formula (3), all the internal subindexes are taken as equivalent.

Based on the content, the given indices are coefficients or rates of the risk change. Thus, the corresponding risk (deterioration of the economic situation, unemployment or losses during quarantine) increases at $I_{i}>100 \%$ but decreases at $I i<100 \%$.

4. The internal structure of each sub-index provides the possibility to fully determine the impact of internal factors (both its quantity and direction) on its change. Similarly, the problem can be solved by the structure of the composite index of the risk changes in the SLR system.

5. The above methodology for assessing the risks in the labour field and in the SLR system can be used in the development of possible scenarios in case of changes in quarantine restrictions, the introduction of adaptive quarantine or its strengthening. At the same time, the values of the corresponding indicators can be determined by expert assessments based on the coronavirus crisis scenarios in the country, and sub-indices are calculated according to the above ratios (formulas 1, 2, 3).

6. The above methodology is an open system. That is, given the emergence of new types of risks or the expansion of internal indicators of their determination, it is possible to assess the changes in the corresponding risks for any contrastive periods based on this ratio without violating the basic methodological approaches.

The implementation of the above methodology for risk assessment in the SLR system includes the sequence of solving the following tasks:

1. Concept identification of all internal factors and indicators of their determination to assess the relevant sub-indices.

2. Formation of the information component for the quantitative assessment of subindices.

3. Determination of the weighting coefficients of the impact of each indicator on the sub- 
index level.

4. Assessment of the change in each of the determined sub-indices and the composite index of risk changes in the SLR under quarantine restrictions.

5. Systematisation and determination of the main factors of the risk change.

6. Development of basic recommendations and mechanisms for their implementation in the system of management decisions to minimise the negative consequences of social risks.

\section{Results}

Testing of the methodology for assessing socio-economic risks and analysing perils in the field of labour and employment.

The first component of the composite index of assessing socio-economic risks in the labour market and employment includes external factors of risk emergence and occurrence. It is related to changes in the economic situation in the country during quarantine restrictions in the $2^{\text {nd }}$ quarter and the first half of 2020 . The main indicators based on which the sub-index of changes in economic conditions is calculated are the

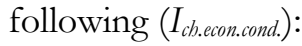

- rate of change in the gross domestic product (GDP) (at constant prices of 2016);

- rate of change in the gross value added (GVA);

- index of change in the production of basic industries (IPBI);

- index of economic sentiment (IES);

- index of consumer confidence;

- index of business confidence.

Measurement indicators and sources of information are given in Table. 2. Based on the fact that strict quarantine measures were introduced in the early $2^{\text {nd }}$ quarter of 2020, all indicators are listed in the rate or coefficient values relative to the $4^{\text {th }}$ quarter of 2019 chosen as the basis for comparison.

Table 2. Indicators for assessing changes in economic conditions of socio-economic risks in the labour market

\begin{tabular}{|c|c|c|c|c|c|c|c|}
\hline \multirow[b]{2}{*}{ Indicators } & \multirow{2}{*}{$\begin{array}{l}\text { Conventional } \\
\text { sign }\end{array}$} & \multirow{2}{*}{$\begin{array}{c}4^{\text {th }} \\
\text { quarter } \\
\text { of } 2019\end{array}$} & \multicolumn{4}{|c|}{2020} & \multirow[b]{2}{*}{ Source of information } \\
\hline & & & $\begin{array}{l}1^{\text {st }} \\
\text { qua. }\end{array}$ & $\begin{array}{l}2^{\text {nd }} \\
\text { qua. }\end{array}$ & \begin{tabular}{|c|}
$1^{\text {st }}$ \\
half
\end{tabular} & $\begin{array}{c}2^{\text {nd }} \text { half } \\
\text { (estimated) }\end{array}$ & \\
\hline $\begin{array}{l}\text { 1. GDP growth } \\
\text { (decline) rate, } \% \text { to } \\
\text { the prev. period (at } \\
\text { const. prices in } \\
\text { 2016) }\end{array}$ & - & 3,0 & $-1,3$ & $-11,4$ & $-12,6$ & $-7,8$ & $\begin{array}{l}\text { State Statistics Service of Ukraine (SSSU), } \\
\text { Inflation Report of the National Bank of } \\
\text { Ukraine (NBU) (Natsionalnyi bank..., July } \\
\text { 2020; Natsionalnyi bank..., October 2020; } \\
\text { Derzhavna sluzhba statystyky..., 2020) }\end{array}$ \\
\hline $\begin{array}{l}\text { 2. GDP change } \\
\text { rate, } \% \text { to the } 4^{\text {th }} \\
\text { qua. of } 2019\end{array}$ & $\mathrm{k}_{11}$ & 100,0 & 98,7 & 87,4 & - & - & Estimated indicators \\
\hline $\begin{array}{l}\text { 3. GVA change } \\
\text { rate, } \% \text { to the } 4^{\text {th }} \\
\text { qua. of } 2019\end{array}$ & $\mathrm{k}_{12}$ & 100,0 & - & 89,5 & - & - & $\begin{array}{l}\text { Calculated based on the SSSU data } \\
\text { (Derzhavna sluzhba statystyky..., 2020) }\end{array}$ \\
\hline $\begin{array}{l}\text { 4. IPBI in relation } \\
\text { to: } \\
\text { the previous } \\
\text { quarter }\end{array}$ & - & 0,974 & 0,971 & 0,88 & 0,854 & - & $\begin{array}{l}\text { NBU Inflation Report, October } 2020 \\
\text { (Natsionalnyi bank..., October 2020) }\end{array}$ \\
\hline $\begin{array}{l}\text { to the } 4^{\text {th }} \text { qua. of } \\
2019\end{array}$ & $\mathrm{k}_{13}$ & 1,0 & 0,971 & 0,854 & - & - & $\begin{array}{l}\text { NBU Inflation Report, October } 2020 \\
\text { (Natsionalnyi bank..., October 2020) }\end{array}$ \\
\hline
\end{tabular}




\begin{tabular}{|c|c|c|c|c|c|c|c|}
\hline \multirow[b]{2}{*}{ Indicators } & \multirow[b]{2}{*}{$\begin{array}{l}\text { Conventional } \\
\text { sign }\end{array}$} & \multirow{2}{*}{\begin{tabular}{|c|}
$4^{\text {th }}$ \\
quarter \\
of 2019 \\
\end{tabular}} & \multicolumn{4}{|c|}{2020} & \multirow[b]{2}{*}{ Source of information } \\
\hline & & & $\begin{array}{c}1^{\text {st }} \\
\text { qua. }\end{array}$ & $\begin{array}{l}2^{\text {nd }} \\
\text { qua. }\end{array}$ & $\begin{array}{c}1^{\text {st }} \\
\text { half }\end{array}$ & $\begin{array}{c}2^{\text {nd }} \text { half } \\
\text { (estimated) }\end{array}$ & \\
\hline $\begin{array}{l}\text { 5. IES (in relation } \\
\text { to the } 4^{\text {th }} \text { quarter of } \\
\text { 2019) }\end{array}$ & $\mathrm{k}_{14}$ & 1,0 & 1,056 & 0,731 & 0,772 & 0,814 & $\begin{array}{l}\text { NBU Inflation Report, October } 2020 \\
\text { (Natsionalnyi bank..., October 2020) }\end{array}$ \\
\hline $\begin{array}{l}\text { 6. Index of } \\
\text { consumer } \\
\text { confidence (in } \\
\text { relation to the the } \\
4^{\text {th }} \text { quarter of 2019) }\end{array}$ & $\mathrm{k}_{15}$ & 1,0 & 0,881 & 0,838 & 0,738 & 0,801 & $\begin{array}{l}\text { NBU Inflation Report, October 2020 } \\
\text { (Natsionalmyi bank..., October 2020) }\end{array}$ \\
\hline $\begin{array}{l}\text { 7. Index of } \\
\text { business } \\
\text { confidence (in } \\
\text { relation to the the } \\
4^{\text {th }} \text { quarter of 2019) }\end{array}$ & $\mathrm{k}_{16}$ & 1,0 & - & 0,62 & - & - & $\begin{array}{l}\text { Calculated as a weighted average by sectors } \\
\text { of economic activity (SEA) } \\
\text { (manufacturing, construction, trade, } \\
\text { services) according to the NBU Inflation } \\
\text { Report (Natsionalmyi bank..., July 2020; } \\
\text { Natsionalmyi bank..., October 2020) }\end{array}$ \\
\hline
\end{tabular}

Source: developed by the authors

The economic recession and strict quarantine measures imposed due to the COVID-19 pandemic have led to a significant decline in key economic development indicators. Therefore, the subindex of change in the economic conditions is seen in the context of its increasing impact on the risk occurrence. In this case, the indicators given in Table 2 are considered as destimulators, and the subindex is calculated by this ratio:

$I_{\text {ch.econ.cond. }}=\sqrt[6]{\prod_{j=1}^{6}\left(1: k_{i j}\right)}=\sqrt[6]{\frac{1}{0,874} \cdot \frac{1}{0,895} \cdot \frac{1}{0,854} \cdot \frac{1}{0,731} \cdot \frac{1}{0,838} \cdot \frac{1}{0,62}}=$

$\sqrt[6]{1,144 \cdot 1,117 \cdot 1,171 \cdot 1,368 \cdot 1,193 \cdot 1,613}=\sqrt[6]{3,939}=1,257$ or $125,7 \%$

Thus, the economic conditions that cause the probability of emergence and occurrence of socio-economic risks increased by $25.7 \%$ in the $2^{\text {nd }}$ quarter of 2020 compared to the $4^{\text {th }}$ quarter of 2019. The greatest negative impact is related to a significant decline in the index of business confidence (by 38\%) and the index of economic sentiment (by 26.9\%). This index can be described in the context of assessing the deterioration of the economic situation. If we take its inverse value, then the index of change (deterioration) of the economic situation will be as follows:

$I_{\text {econ.sit. }}=1: I_{\text {ch.econ.cond } .}=1: 1,257=0,796$ or $79,6 \%$

Thus, deterioration of the economic situation by $20.4 \%$ is accompanied by $25.7 \%$ more intensive development of economic conditions favouarable for emergence and occurrence of socio-economic risks in the field of employment.

The determination of risks directly in the labour market is based on the system of indicators shown in Table 3. The system of indicators corresponds to the content of the unemployment risks. These are indicators of changes in both the volume and the level of employment. The structure of the unemployment assessment includes indicators of general unemployment determined according to the ILO methodology and the estimated values provided by the State Employment Service according to the official statistics and the survey results.

In the study, these estimates are determined as the lower and upper limits of the respective indicator. Under these conditions, the subindex is calculated in two contexts by the lower and upper limits, which create the allowable interval of its change.

The system of indicators listed in Table 3 does not include indicators of remote employment since this form of employment officially appeared only in 2020, which makes it impossible to determine the relevant indicators of change for the period under study. 
Table 3. Indicators of assessment of the sub-index change in the unemployment risk

\begin{tabular}{|c|c|c|c|c|c|c|c|}
\hline \multirow[b]{2}{*}{ Indicators } & \multirow[b]{2}{*}{$\begin{array}{l}\text { Impact } \\
\text { direction }\end{array}$} & \multirow[b]{2}{*}{$\begin{array}{c}\text { Conventional } \\
\text { sign }\end{array}$} & \multirow[b]{2}{*}{$\begin{array}{l}4^{\text {th }} \\
\text { quarter } \\
\text { of } 2019\end{array}$} & \multicolumn{2}{|c|}{2020} & \multirow{2}{*}{$\begin{array}{c}\text { Weighting } \\
\text { coefficients } \\
\left(\mathrm{W}_{\mathrm{j}}\right) \text { lower } \\
\text { limit/upper } \\
\text { limit } \\
\end{array}$} & \multirow[b]{2}{*}{ Source of information } \\
\hline & & & & $\begin{array}{c}1^{\text {st }} \\
\text { quarter }\end{array}$ & \begin{tabular}{|c|}
$2^{\text {nd }}$ \\
quarter
\end{tabular} & & \\
\hline $\begin{array}{l}\text { 1. Employed population } \\
\text { aged } 15-70 \text {, thousand } \\
\text { people }\end{array}$ & destimulator & - & 16501,8 & 16574,5 & 15707,9 & $\underline{0,49173}$ & $\begin{array}{c}\text { SSSU (Derzhavna sluzhba statystyky..., } \\
\text { n.d.) }\end{array}$ \\
\hline $\begin{array}{l}\text { 2. Employment rate at the } \\
\text { age of } 15-70, \%\end{array}$ & destimulator & $\mathrm{k}_{21}$ & 57,9 & - & 55,2 & $\frac{0,49173}{0,40476}$ & $\begin{array}{c}\text { SSSU (Derzhavna sluzhba statystyky..., } \\
\text { 2020; Derzhavna sluzhba statystyky..., } \\
\text { n.d.) }\end{array}$ \\
\hline $\begin{array}{l}\text { 3. Number of employees, } \\
\text { thousand people }\end{array}$ & destimulator & $\mathrm{k}_{22}$ & 7998,2 & 7842,3 & 7671,3 & $\frac{0,240146}{0,19760}$ & $\begin{array}{l}\text { SSSU (Derzhavna sluzbba statystyky..., } \\
\text { 2020; Derzhaina sluzhba statystyky..., } \\
\text { n.d.) }\end{array}$ \\
\hline $\begin{array}{l}\text { 4. Rate of change in the } \\
\text { employed population, } \% \\
\text { to the } 4^{\text {th }} \text { quarter of } 2019\end{array}$ & destimulator & - & 100,0 & 100,4 & 95,2 & $\frac{0,49173}{0,40476}$ & Calculated based on the SSSU data \\
\hline $\begin{array}{l}\text { 5. Unemployment } \\
\text { (according to the ILO } \\
\text { methodology), thousand } \\
\text { people }\end{array}$ & stimulator & - & 1564,5 & 1548,9 & 1712,0 & - & $\begin{array}{c}\text { SSSU (Derzhavna slu₹bba statystyky..., } \\
\text { 2020; Derzhavna sluzbba statystyky..., } \\
\text { n.d.) }\end{array}$ \\
\hline 6. Unemployment rate, $\%$ : & & - & & & & & \\
\hline $\begin{array}{l}\text { 6.1. according to the ILO } \\
\text { methodology }\end{array}$ & stimulator & - & 8,7 & 8,6 & 9,9 & - & $\begin{array}{l}\text { SSSU (Derzhavna sluzbba statystyky..., } \\
\text { 2020; Derzhavna sluzbba statystyky..., } \\
\text { n.d.) }\end{array}$ \\
\hline $\begin{array}{l}\text { 6.2. estimated taking into } \\
\text { account dismissal due to } \\
\text { quarantine: }\end{array}$ & stimulator & - & & & & & $\begin{array}{l}\text { Calculated based on the data of the } \\
\text { State Employment Service of Ukraine } \\
\text { (SESU) and the survey (Derzhavna }\end{array}$ \\
\hline - lower limit & & $\mathrm{k}_{23}$ & 8,7 & - & 11,8 & & sluzbba zainiatosti..., 2020; Info Sapiens, \\
\hline - upper limit & & $k_{23}$ & - & - & 24,0 & $\frac{0,066907}{0,112}$ & $\begin{array}{l}\text { 2020; Kyivskyi mizhnarodnyi..., 2020; } \\
\text { Research \& Branding..., 2020; } \\
\text { Sotsiolobichna brupa .., 2020; Savchuk, } \\
\text { 2020; Sholomitskaya, 2020) }\end{array}$ \\
\hline $\begin{array}{l}\text { 7. Hidden unemployment } \\
\text { (unpaid leave, part-time } \\
\text { employment, } \\
\text { underemployment), } \\
\text { thousand people: }\end{array}$ & stimulator & & & & & & $\begin{array}{l}\text { SESU and survey data [(Derzhavna } \\
\text { sluzbba zainiatosti..., 2020; Info Sapiens, } \\
\text { 2020; Kyivskyi mizhnarodnyi..., 2020; } \\
\text { Research \& Branding..., 2020; }\end{array}$ \\
\hline - lower limit & & - & 313,5 & 364,3 & 454,7 & $\underline{0,014234}$ & Sotsiolobicbna brupa..., 2020; Savchuk, \\
\hline - upper limit & & - & - & - & 3100 & 0,08 & \\
\hline $\begin{array}{l}\text { 8. Hidden unemployment } \\
\text { rate, } \% \text { of the employed } \\
\text { population }\end{array}$ & stimulator & & & & & & Calculated based on the data of SSSU, \\
\hline - lower limit & & $\mathrm{k}_{24}$ & 1,9 & 2,2 & 3,12 & 0,014234 & \\
\hline - upper limit & & $\mathrm{k}_{24}$ & 5,0 & - & 19,7 & 0,08 & \\
\hline $\begin{array}{l}\text { 9. Informal } \\
\text { employment, } \% \text { of } \\
\text { employed population }\end{array}$ & stimulator & $\mathrm{k}_{25}$ & 20,9 & - & 29,0 & $\frac{0,14262}{0,117}$ & 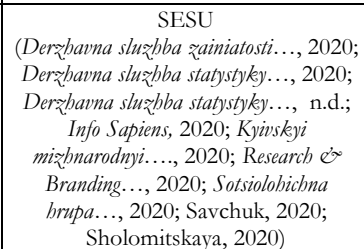 \\
\hline $\begin{array}{l}\text { 10. Estimated mass } \\
\text { dismissal: }\end{array}$ & stimulator & & & & & & \\
\hline - thousand people & & $\mathrm{k}_{26}$ & 109,6 & - & 160,6 & $\frac{0,005027}{0,0041}$ & $\begin{array}{c}\text { SESU (Derzhavna sluzhba zainiatosti..., } \\
2020)\end{array}$ \\
\hline - $\%$ to the staff employed & & $\mathrm{k}_{26}$ & 1,37 & - & 2,1 & $\frac{0,005027}{0,0041}$ & Calculated based on the SESU data \\
\hline $\begin{array}{l}\text { 11. Loss of working } \\
\text { hours, \% to the working } \\
\text { time fund: }\end{array}$ & stimulator & & & & & & Calculated by the authors according \\
\hline - lower limit & & $\mathrm{k}_{27}$ & 4,1 & & 8,0 & $\underline{0,039336}$ & \\
\hline - upper limit & & $\mathrm{k}_{27}$ & - & & 20,8 & 0,0842 & \\
\hline
\end{tabular}

Source: developed by the authors 
Weighting coefficients (Wj) are calculated according to two estimates, i.e. the lower and upper limits of change in the relevant indicators. The coefficients are determined as the share of the population among which there may be the occurrence of the corresponding unemployment risk. Under these conditions, the sub-indices of the unemployment risk will be as follows:

- by the lower limit of change in indicators and weighting coefficients:

$$
\begin{aligned}
& I_{\text {ch.unempl.risk }}^{\text {l.l. }}=\sqrt[\sum W_{j}]{\prod_{j=1}^{7} k_{2 j}^{W_{j}}}={\frac{57,9^{0,49173}}{55,2}}^{\frac{7998,2^{0,24016}}{7671,3}} \cdot \frac{11,8}{8,7}^{0,066907} \cdot{\frac{3,12^{0,014234}}{1,9}} \text {. } \\
& \frac{29,0}{20,9}^{0,14262} \cdot{\frac{160,6^{0,005027}}{109,6}}^{8^{8,0}}{ }^{0,039336}=1,02376 \cdot 1,010072 \cdot 1,0206 \cdot 1,00708 \cdot 1,047823 \cdot \\
& 1,001923 \cdot 1,026643=1,146 \text { or } 114,6 \% \\
& \text { - by the upper limit: }
\end{aligned}
$$

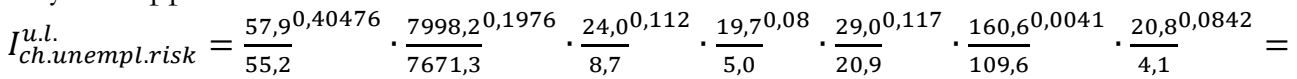

$$
\begin{aligned}
& 1,0195 \cdot 1,00828 \cdot 1,12036 \cdot 1,116 \cdot 1,039 \cdot 1,001567 \cdot 1,1465=1,533 \text { or } 153,3 \%
\end{aligned}
$$

These values of the unemployment risk sub-indices show their significant increase. By the lower limit, the risk increased by $14.6 \%$ in the $2^{\text {nd }}$ quarter of 2020 compared to the basic period, and by the upper limit, it increased by $53.3 \%$.

Thus, the interval of increase in the unemployment risk can be from 14.6 to $53.3 \%$. According to the internal structure of the sub-index, taking into account the amount of the population where the corresponding risk occurs the growth of informal employment and loss of working hours have the strongest impact due to the unemployment including hidden. The third position in terms of the impact on the risk growth is occupied by a significant decline in employment. This ratio is based on the sub-index calculated at the lower limit of change in indicators. At the same time, according to the sub-index determined by the upper limit, the loss of working hours has the strongest impact. The second position is occupied by the rise of unemployment, and the third one is taken by hidden unemployment. Given that a more objective assessment of the sub-index of the employment growth is its value at the upper limit of the change in indicators, we can rank the main factors leading to the unemployment risk growth according to the reduction of their impact. These are loss of working hours, rise of unemployment, including hidden, growth of informal employment. The third component of the assessment of socio-economic risks in the labour sphere is related to determining socio-economic consequences of their occurrence, which are considered as socio-economic losses. First of all, we are talking about the loss of income, including labour, due to the dismissal of employees, their part-time employment, fully or partially paid leave. As a result, the poverty rate increases, and the differentiation of the population deepens according to the per capita income. At the macro level, falling income is accompanied by a decrease in the purchasing power of the population and consumer demand in general, and its structure. The spread of remote employment, growth of informal employment, growth of the number of workers who have "hidden unemployment" are accompanied by the growth of social insecurity of the employed population.

The structure of indicators for determining the sub-indices of change in losses under the condition of risk occurrence is shown in Table 4, and its values by the lower and upper limits will be as follows:

- by the lower limit of the change in indicators: 
$I_{\text {ch.loss }}^{\text {l.l. }}=\prod_{j=1}^{5} k_{3 j}^{W_{j}}=\frac{1}{0,927}^{0,374} \cdot{\frac{14,9^{0,021}}{11,4}}^{\frac{45^{23,1}}{23,169}} \cdot{\frac{43,9^{0,062}}{32,3}}^{0.47,4^{0,374}}=1,0287 \cdot 1,00564 \cdot$

$1,1193 \cdot 1,0192 \cdot 1,0625=1,2$ or $120 \%$.

- by the upper limit of the change in indicators:

$I_{\text {ch.loss }}^{\text {u.l. }}=\frac{1}{0,927}^{0,346} \cdot{\frac{43,7^{0,057}}{11,4}}^{4_{23,1}^{45^{0,156}}} \cdot{\frac{42,7^{0,095}}{32,3}}^{\frac{47,4^{0,346}}{45,4}}=1,0265 \cdot 1,0796 \cdot 1,1096 \cdot 1,08 \cdot$

$1,015=1,348$ or $134,8 \%$.

Thus, socio-economic losses in case of the labour risk occurrence increased from $20 \%$ (by the lower limit) to $34.8 \%$ (by the upper limit) in the $2^{\text {nd }}$ quarter of 2020 . In the structure of the sub-index determined by the lower limit of change in indicators, the rise of poverty by almost 2 times from $23.1 \%$ (as of the $4^{\text {th }}$ quarter of 2019) to 45\% (according to expert estimates) has the greatest impact. The second place in terms of impact belongs to the reduction of salary in the structure of the household income. There is a slight difference in the power of the impact of internal factors in the sub-index structure, which is calculated by the upper limit of change in indicators.

Three factors have almost the same impact. Thus, the poverty rate remains in the first place in terms of impact; the second and the third places are occupied by the growth of social insecurity of the employed population, and the share of the population that lost livelihood during strict quarantine.

Table 4. Indicators for assessing the sub-index of changes in the level of losses in case of risk occurrence in the labour field

\begin{tabular}{|c|c|c|c|c|c|c|c|}
\hline \multirow[b]{2}{*}{ Indicators } & \multirow[b]{2}{*}{$\begin{array}{l}\text { Impact } \\
\text { direction }\end{array}$} & \multirow{2}{*}{$\begin{array}{l}\text { Conve- } \\
\text { ntional } \\
\text { sign }\end{array}$} & \multirow{2}{*}{$\begin{array}{l}4^{\text {th }} \\
\text { quarter } \\
\text { of } 2019\end{array}$} & \multicolumn{2}{|c|}{2020} & \multirow{2}{*}{\begin{tabular}{|c|} 
Weighting \\
Coefficients \\
$\left(\mathrm{W}_{\mathrm{i}}\right)$ lower \\
limit/upper \\
limit \\
\end{tabular}} & \multirow[b]{2}{*}{ Source of information } \\
\hline & & & & \begin{tabular}{c|}
$1^{\text {st }}$ \\
quarter
\end{tabular} & $\begin{array}{c}2^{\text {nd }} \\
\text { quarter }\end{array}$ & & \\
\hline $\begin{array}{l}\text { 1. The rate of change in real income } \\
\text { of the population, } \% \text { to the } 4^{\text {th }} \text { qua. } \\
\text { of } 2019\end{array}$ & destimulator & $\mathrm{k}_{31}$ & 100,0 & - & 92,7 & $\frac{0,374}{0,346}$ & $\begin{array}{c}\text { SSSU (Derzhavna sluzhba statystyky..., } \\
\text { 2020; Der₹havna sluzhba statystyky..., } \\
\text { n.d.) }\end{array}$ \\
\hline $\begin{array}{l}\text { 2. The share of the employed } \\
\text { population that lost their livelihood } \\
\text { (unemployed }+ \text { hidden } \\
\text { unemployment), \% to the } \\
\text { employed: }\end{array}$ & \multirow[t]{3}{*}{ stimulator } & & & & & & \multirow{3}{*}{$\begin{array}{l}\text { Calculated based on the SSSU data } \\
\text { and the survey data (Derzhavna } \\
\text { sluzhba zainiatosti..., 2020; Derzhavna } \\
\text { sluzbba statystyky..., 2020; Derzhavna } \\
\text { sluzbba statystyky..., n.d.; Info Sapiens, } \\
\text { 2020; Kyivskyi mizhnarodnyi..., 2020; } \\
\text { Research \& Branding..., 2020; } \\
\text { Sotsiolohichna brupa..., 2020; Savchuk, } \\
\text { 2020; Sholomitskaya, 2020) }\end{array}$} \\
\hline - lower limit & & $\mathrm{k}_{32}$ & 11,4 & 11,54 & 14,9 & $\underline{0,021}$ & \\
\hline - upper limit & & $\mathrm{k}_{32}$ & - & - & 43,7 & $\frac{0,021}{0,057}$ & \\
\hline $\begin{array}{l}\text { 3. Poverty level, } \% \text { of the } \\
\text { population, whose income is less } \\
\text { than the real subsistence level }\end{array}$ & stimulator & $\mathrm{k}_{33}$ & 23,1 & - & 45,0 & $\frac{0,169}{0,156}$ & $\begin{array}{l}\text { SSSU and expert assessments as for } \\
\text { the } 2^{\text {nd }} \text { quarter of } 2020 \text { (Derzhavna } \\
\text { sluzbba statystyky..., n.d.; Didenko, } \\
\text { 2020) }\end{array}$ \\
\hline $\begin{array}{l}\text { 4. The level of social insecurity of } \\
\text { the employed population (that has } \\
\text { lost their livelihood and is } \\
\text { informally employed), } \% \text { of the } \\
\text { employed population: }\end{array}$ & \multirow[t]{3}{*}{ stimulator } & & & & & & \multirow[t]{3}{*}{ Calculated by the authors } \\
\hline - lower limit & & $\mathrm{k}_{34}$ & 32,3 & - & 43,9 & $\frac{0,062}{0,095}$ & \\
\hline - upper limit & & $\mathrm{k}_{34}$ & 32,3 & - & 72,7 & $\frac{0,062}{0,095}$ & \\
\hline $\begin{array}{l}\text { 5. The salary share in the household } \\
\text { income structure, } \%\end{array}$ & destimulator & $\mathrm{k}_{35}$ & 47,4 & 50,0 & 45,4 & $\frac{0,374}{0,346}$ & $\begin{array}{l}\text { SSSU (Derzhavna sluzhba statystyky..., } \\
\text { 2020; Derzhavna sluzhba statystyky..., } \\
\text { n.d.) }\end{array}$ \\
\hline
\end{tabular}

Source: developed by the authors 
According to the ratio (formula 3) the generalised index of risk change in the social and labour relations will be the following:

- by the lower limit of change in sub-indices:

$I_{S L R \text { risk }}^{l . l .}=1,257^{0,225} \cdot 1,146^{0,173} \cdot 1,2^{0,602}=1,0528 \cdot 1,0238 \cdot 1,1156=1,202$ or $120,2 \%$

- by the upper limit of change in sub-indices:

$I_{S L R \text { risk }}^{u . l .}=1,257^{0,2077} \cdot 1,533^{0,1923} \cdot 1,348^{0,6}=1,0486 \cdot 1,0856 \cdot 1,196=1,361$ or $136,1 \%$

In general, taking into account changes in the economic situation in the context of the COVID-19 pandemic, the growth of risks of unemployment and socio-economic losses, the generalised risk in the system of social and labour relations grew by $20.2 \%$ (by the lower limit) and by $36.1 \%$ (by the upper limit). According to the two variants of calculations, the risk that determines the increase in losses in case of its occurrence has the greatest socio-economic consequences (loss of income and basic livelihood resources, and the growth of social insecurity). They largely determine risks in the system of social and labour relations.

Table 5 shows the systematisation of the main factors of growth of risks and perils in the system of social and labour relations due to the impact of the COVID-19 pandemic.

Table 5. Systematisation of the most important factors of socio-economic risks in the labour sphere under quarantine restrictions

\begin{tabular}{|l|c|c|c|l|}
\hline $\begin{array}{l}\text { Component of risk } \\
\text { changes in the labour } \\
\text { sphere }\end{array}$ & $\begin{array}{r}\text { Conventional } \\
\text { sign }\end{array}$ & $\begin{array}{r}\text { Level of } \\
\text { indices } \\
\text { (sub-indices) }\end{array}$ & $\begin{array}{l}\text { The most important factors of change, } \\
\text { - by the level of impact reduction }\end{array}$ \\
\cline { 2 - 5 } & $\begin{array}{c}\text { lower } \\
\text { limit }\end{array}$ & $\begin{array}{c}\text { upper } \\
\text { limit }\end{array}$ & \\
\hline $\begin{array}{l}\text { 1. Change in economic } \\
\text { conditions of risk } \\
\text { occurrence }\end{array}$ & $I_{\text {ch.econ.cond. }}$ & 1,257 & 1,257 & $\begin{array}{l}\text { Decrease in the index of business activity } \\
\text { and the index of economic sentiment }\end{array}$ \\
\hline $\begin{array}{l}\text { 2. Change in the level } \\
\text { of unemployment in } \\
\text { the labour market }\end{array}$ & $I_{\text {ch.unempl. }}$ & 1,146 & 1,533 & $\begin{array}{l}\text { Growth of informal employment, loss of } \\
\text { working hours, rise of unemployment, } \\
\text { including hidden }\end{array}$ \\
\hline $\begin{array}{l}\text { 3. Change in socio- } \\
\text { economic losses in the } \\
\text { context of the COVID- } \\
\text { 19 pandemic }\end{array}$ & $\mathrm{I}_{\text {ch.loss. }}$ & 1,2 & 1,348 & $\begin{array}{l}\text { Rise of poverty, reduction of the salary } \\
\text { share in the income structure, increase in } \\
\text { the level of social insecurity of the } \\
\text { employed population, and the share of the } \\
\text { population that lost livelihoods during } \\
\text { quarantine }\end{array}$ \\
\hline $\begin{array}{l}\text { 4. Composite index of } \\
\text { risk changes in the } \\
\text { system of social and } \\
\text { labour relations }\end{array}$ & ISLR risk & 1,202 & 1,361 & $\begin{array}{l}\text { Increase in socio-economic losses of the } \\
\text { risk occurrence and economic conditions } \\
\text { of their emergence }\end{array}$ \\
\hline
\end{tabular}

Source: developed by the authors

The ranking of factors of risk emergence and occurrence in the labour sphere, and social and economic consequences of such occurrence given in Table 5 provide scientific and 
methodical substantiation of the development of the administrative decisions. They should be connected with both mitigation of the negative impact of risks, and with possibilities of their prevention in case of stricter quarantine restrictions by the end of the year.

The main measures of state support and social protection should be aimed at ensuring compensation for economic losses of the population, i.e., income, livelihood resources. These mechanisms can be implemented under the condition of the growth of business in all types of economic activities. The concern is caused by the growth of informal employment, the number of people with "hidden unemployment" accompanied by the increase in the level of social insecurity of the employed population, and the spread of their precarity.

Due to the objective reasons, some of the socio-economic risks that may occur in the system of social and labour relations have not been assessed according to the developed methodology. This is mainly explained by the lack of objective statistical data for the period of the methodology development and testing.

Currently, due to these reasons, it is almost impossible to assess the socio-economic consequences of risks associated with loss of social status, breaking of social elevators, deepening the differentiation of income and expenditure levels, the development of regressive social mobility of the population, etc. All of them can be included as separate components in the developed methodology, provided that there is a sufficient amount of objective information.

\section{Conclusion}

The proposed methodology for assessing socio-economic risks is based on the principles of the development of the European System of Social Indicators (ESSI). It can be used as a practical tool for continuous monitoring and analysis of changes in the labour sphere, contrasting and comparing relevant risks in the national labour market, the European Union, and in the whole world.

The algorithm of the methodology allows assessing not directly the risk level, but its changes over a certain period of research or in comparison with some countries, the EU, and the world.

The internal structure of sub-indices of risks in the labour sphere provides an opportunity to rank the main factors of their change, which serves as a scientific and methodological substantiation for developing programmes, mechanisms, and management decisions to prevent risks and mitigate the negative consequences of their occurrence.

Based on the developed methodology, it is possible to assess changes in the risks of the labour sphere by the options of possible values of internal indicators, which provides opportunities for the development of scenario approaches.

The composite index of risk changes in the system of social and labour relations varied from $120.2 \%$ (lower limit) to $136.1 \%$ (upper limit) in the $2^{\text {nd }}$ quarter of 2020 compared to the fourth quarter of 2019, i.e. risks of the labour sphere increased by almost a third during the first half of 2020. The greatest impact on such a change in risks is explained by a significant worsening of consequences of risk occurrence, which are calculated according to the methodology by the sub-index of changes in socio-economic losses during the COVID-19 pandemic. 
The internal structure of sub-indices of emergence and occurrence of risks in the labour sphere provides an opportunity to systematise and rank the factors according to the level of impact on the change of both sub-indices and the composite index as a whole. As their impact reduced, the following sequence was obtained:

- rise of poverty and the share of the employed population, which lost the means of subsistence of basic needs during strict quarantine;

- reduction of salaries and income in the income structure of the population;

- growth of social insecurity of the population;

- loss of working hours;

- rise of unemployment, including hidden;

- growth of informal employment;

- decline in the index of business activity and the index of economic sentiment.

\section{Acknowledgement}

The study is performed within the project "Overcoming Socio-Economic Risks and Perils in the Field of Labour and Employment of Ukraine in the Context of the COVID-19 Pandemic" (2020.01 / 0253)

\section{References}

Berezina, S. (2018). Social risks of probabilistic type and their assessment. Ekonomika ta derz̧hava, 3, 33-39.

Derzhavna sluzhba statystyky Ukrainy. (2020). Employment and unemployment in the second quarter of 2020.

Retrieved from http://www.ukrstat.gov.ua/express/expr2020/09/118.doc

Derzhavna sluzhba statystyky Ukrainy. (n.d.) Retrieved from http://www.ukrstat.gov.ua

Derzhavna sluzhba zainiatosti Ukrainy. (2020). The situation on the labor market and the activities of the State Employment Service in January-September 2020. Retrieved from https://www.dcz.gov.ua/sites/default/files/infofiles/sytuaciya_na_rp_ta_diyalnist_dsz_0.pdf.

Didenko, S. (2020). Labor market: assessment and forecast of employment of Ukrainians in 2020. Retrieved from https://ua.news/ru/rynok-truda-otsenka-y-prognoz-zanyatosty-ukrayntsev-v-2020-godu/

Info Sapiens (2020). 60\% ukraintsiv zaznaly finansovykh zbytkiv vnaslidok epidemii koronavirusu. Retrieved from https:// sapiens.com.ua/ua/publication-single-page?id=114

Kyivskyi mizhnarodnyi instytut sotsiolohii. (2020). Otsinka uspishnosti vlady ta reaktsiia suspilstva na epidemiiu koronavirusu ta politychni podii $\mathrm{v}$ kraini. Retrieved from https: / $/$ www.kiis.com.ua/?lang=ukr\&cat=reports\&id=930\&page $=1$

Nadraha, V. (2013). Assessment of social risks: the problem of choosing methodology and tools. Finance of Ukraine, 12, 70-77.

Nadraha, V. (2015). Social risks: essence, analysis, possibilities of influence: monograph. Kyiv: "PP Serdyuk VL".

Natsionalnyi bank Ukrainy. (2020). Inflation report. July 2020. Retrieved from https://bank.gov.ua/admin_uploads/article/JR_2020_Q3.pdf.

Natsionalnyi bank Ukrainy. (2020). Inflation report. October 2020. Retrieved from https://bank.gov.ua/admin_uploads/article/JR_2020_Q4.pdf?v=4

Novikova, O. \& Shamileva, L. (2020). Evaluation of social and economic insecurity risks for employees during structural transformations in the modern labor market. Social and labor relations: theory and practice, Vol. 10, Iss. 1, 1-10. Doi: 10.21511/slrtp.10(1).2020.01

Research \& Branding Group. (2020). Vseukrainske rolinhove doslidzhennia «Rubikon»: Khvylia 3. Retrieved from http://rb.com.ua/uk/blog-uk/rubicon_wave_3/

Saienko, Yu. (2004). Methodology and methods of determining integrated social indicators. Kyiv: Institute of Sociology of the National Academy of Sciences of Ukraine. 
Savchuk, D. (2020). Press release "Omnibus Info Sapiens", April 2020. Retrieved from https://sapiens.com.ua/publications/socpol-research/122/Press-Employment12.05.2020_fin.pdf

Sholomitskaya, E. (2020). Iz-za karantina rabotu mogli poteryat okolo 2,5 mln ukraintsev. I eto ne konets. Retrieved from https://biz.liga.net/ekonomika/all/opinion/iz-za-karantina-rabotu-moglipoteryat-okolo-25-mln-ukraintsev

Sotsiolohichna hrupa «Reitynh». (2020). Ukraina na karantyni: monitorynh suspilnykh nastroiv. Retrieved from http://ratinggroup.ua/research/ukraine/7ffba32fbbac0ba2a21713d0a9f2c5d5.html

Sydorchuk, O. (2018). Methodical approaches to measuring economic insecurity in the context of social dangers. Naukovyi visnyk Uzhhorodskoho natsionalnoho universytetu. Seriia: Mizhnarodni ekonomichni vidnosyny ta svitove hospodarstvo, Vol. 18, Part 3, 59-64. 